\title{
Elevated Bmi-I expression is associated with dysplastic cell transformation during oral carcinogenesis and is required for cancer cell replication and survival
}

\author{
MK Kang ${ }^{*, 1,2}$, RH Kim', SJ Kim', FK Yip', K-H Shin ',2, GP Dimri', R Christensen', T Han' and N-H Park ${ }^{1,2,4}$ \\ 'UCLA School of Dentistry, Los Angeles, CA 90095, USA; ' UCLA Jonsson Comprehensive Cancer Center, Los Angeles, CA 90095, USA; ${ }^{3}$ Evanston \\ Northwestern Healthcare Research Institute, Feinberg School of Medicine, Northwestern University, Evanston, IL 60201, USA; ${ }^{4}$ David Geffen School of \\ Medicine at UCLA, Los Angeles, CA 90095, USA
}

\begin{abstract}
Bmi-I is a polycomb group protein that was identified as c-myc cooperating oncogene in murine lymphomagenesis. The current study was undertaken to determine the role of Bmi-I in human oral carcinogenesis. Bmi-I protein and RNA expression levels were markedly enhanced in the cells of oral squamous cell carcinomas (OSCC) compared with that of normal human oral keratinocytes (NHOK). Enhanced-Bmi- I expression was also detected in situ in the archived oral mucosal tissues with cancerous and precancerous histopathology, including that of mild epithelial dysplasia. Thus, Bmi- I expression occurs at a very early stage in oral carcinogenesis. To determine the biological role of Bmi-I in cell proliferation, endogenous Bmi-I was knocked down in actively proliferating SCC4 cells and NHOK by RNA interference. After Bmi-I knockdown, cell replication was severely retarded. However, the expression of pI6 INK4A, a known cellular target of Bmi-I, was not changed in cells with or without Bmi-I knockdown. Furthermore, Bmi-I knockdown in HOK-I6B-BaP-T cells, in which the $\mathrm{p} / 6^{\mathrm{INK} 4 \mathrm{~A}} / \mathrm{pRb}$ pathway was abrogated, led to immediate arrest of replication and loss of viable cells. Thus, our data suggest that Bmi-I may act through pl $6^{\mathrm{INK} 4 \mathrm{~A}}$-independent pathways to regulate cellular proliferation during oral cancer progression.
\end{abstract}

British Journal of Cancer (2007) 96, I26-133. doi:I0.I038/sj.bjc.6603529 www.bjcancer.com

Published online 19 December 2006

(c) 2007 Cancer Research UK

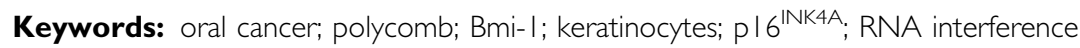

Bmi-1 is a polycomb group (PcG) transcription repressor originally identified as a c-myc cooperating oncogene in murine lymphomas (van Lohuizen et al, 1991; Pirrotta, 1998). Proliferative capacity of leukaemic and normal haemopoietic stem cells derived from $\mathrm{Bmi}_{-1} \mathrm{1}^{-/}$mice was compromised, suggesting the possible role of Bmi-1 in the maintenance of tumour stem cell phenotype (Lessard and Sauvageau, 2003). Bmi-1 is one of the core subunits of the polycomb repressive complex 1 , which regulates the diverse biological processes, including $\mathrm{X}$ chromosome inactivation, carcinogenesis, and stem cell renewal (Li et al, 2006; Sparmann and van Lohuizen, 2006). Cellular target genes of Bmi-1 have been identified and include ink $4 a$ and ink $4 b$ loci, encoding $16^{\mathrm{INK} 4 \mathrm{~A}}$, $\mathrm{p} 19^{\mathrm{ARF}}$, and $\mathrm{p} 15^{\mathrm{INK} 4 \mathrm{~B}}$ (Jacobs et al, 1999). Bmi-1 is believed to promote cellular proliferation by repressing the expression of the ink $4 a$ locus, which plays pivotal roles in the onset of cellular senescence in many different types of human somatic cells (reviewed in Itahana et al, 2004). During normal replication of primary human cells, Bmi-1 expression level is decreased notably in senescent cells (Itahana et al, 2003). When overexpressed, Bmi-1 is able to extend the replicative life span of human diploid

*Correspondence: Professor MK Kang, UCLA School of Dentistry, CHS 43-009, 10833 Le Conte Ave. Los Angeles, CA 90095-1668, USA. E-mail: mkang@dent.ucla.edu

Received 5 July 2006; revised 2 November 2006; accepted 14 November 2006; published online 19 December 2006 fibroblasts (Itahana et al, 2003) and immortalise the post-selection population of human mammary epithelial cells by activation of endogenous telomerase gene, hTERT (Dimri et al, 2002). Therefore, in normal human cells, downregulation of Bmi-1 expression may be important for the establishment of the senescence program.

Cellular senescence is physiologically important because it is a potent tumor suppressor mechanism that must be overcome for cells to be immortalised and transformed (Campisi, 2005; Dimri, 2005). The molecular mechanisms of senescence have therefore been investigated extensively and yielded several important regulators of senescence (Itahana et al, 2004). The intrinsic, telomere-dependent senescence is triggered by accumulation of shortened and dysfunctional telomeres with altered telomeric state (Harley et al, 1990; Karlseder et al, 2002). The extrinsic senescence is telomere-independent and triggered in cells after exposure to environmental factors, such as genotoxic stress, in vitro culture shock, and oncogenic stimuli (Serrano et al, 1997; Ramirez et al, 2001; Itahana et al, 2004; Chen et al, 2005; Dimri, 2005). The onset of extrinsic senescence is frequently associated with induction of $\mathrm{p} 16^{\mathrm{INK} 4 \mathrm{~A}}$ (Itahana et al, 2004). The mechanisms resulting in p16 ${ }^{\text {INK4A }}$ upregulation during senescence are not fully understood, although recent studies found a positive control by ETS1 and negative regulation of its expression by $I d-1, B m i-1$, and $C B X 7$ (Ohtani et al, 2001; Itahana et al, 2003; Gil et al, 2004). In particular, Bmi-1 overexpression is detected in several types of human cancers (Bea et al, 2001; Kim et al, 2004a, b; Breuer et al, 
2005), leading to the hypothesis that Bmi-1 facilitates tumorigenesis by nullifying the $\mathrm{p} 16^{\mathrm{INK} 4 \mathrm{~A}}$-mediated extrinsic senescence pathway.

The current study was undertaken to investigate the role of Bmi-1 in oral carcinogenesis and its functional relationship with p16 ${ }^{\mathrm{INK} 4 \mathrm{~A}}$. We report enhanced expression of Bmi-1 in preneoplastic and cancerous oral epithelial tissues compared with the normal counterparts. The cell lines established from oral squamous cell carcinomas (OSCC) also expressed notably higher level of Bmi-1 compared with those of normal human oral keratinocytes (NHOK). However, the expression levels of Bmi-1 and $16^{\mathrm{INK} 4 \mathrm{~A}}$ were poorly correlated in the OSCC cells. Knockdown of endogenous Bmi-1 led to rapid inhibition of cell proliferation in the OSCC cells, regardless of the presence of functional $\mathrm{p} 16^{\mathrm{INK} 4 \mathrm{~A}}$, $\mathrm{pRb}$ cell cycle inhibitory pathway in these cells. Thus, our results indicate that Bmi-1 may act through p16 $6^{\mathrm{INK} 4 \mathrm{~A}}$-independent pathways to regulate cellular proliferation during oral carcinogenesis.

\section{MATERIALS AND METHODS}

\section{Cells and cell culture}

Primary NHOK cultures were prepared from separated keratinising oral epithelial tissue discarded during routine oral surgery procedures. The cells were cultured in keratinocyte growth medium (KGM) containing a low level $(0.15 \mathrm{mM})$ of $\mathrm{Ca}^{+}{ }^{+}$and supplementary growth factor bullet kit (Cambrex, East Rutherford, NJ, USA). The detailed method of primary culture establishment can be found elsewhere (Kang et al, 2000). BaP-T, SCC4, SCC9, SCC15, FaDu, Tu-139, 1483, HEp-2, HeLa, and RKO cells were cultured as previously described (Rey et al, 2000).

\section{Reverse transcription (RT) - PCR}

Total RNA was isolated from the cultured cells using Trizol $^{\mathrm{TM}}$ reagent (Invitrogen, Carlsbad, CA, USA) and was subjected to RNase-free DNase I digestion at $37^{\circ} \mathrm{C}$ for $2 \mathrm{~h}$ to eliminate any contaminating genomic DNA. Five $\mu \mathrm{g}$ of DNA-free total RNA was dissolved in $15 \mu \mathrm{l} \mathrm{H}_{2} \mathrm{O}$, and $\mathrm{RT}$ reaction was performed in the first strand buffer (Invitrogen) containing $300 \mathrm{U}$ Superscript II (Invitrogen), $10 \mathrm{~mm}$ dithiotrietol, $0.5 \mu \mathrm{g}$ random hexamer (Promega, Madison, WI, USA), and $125 \mu \mathrm{M}$ dNTP. The annealing reaction was carried out for $5 \mathrm{~min}$ at $65^{\circ} \mathrm{C}$, and cDNA synthesis was performed for $2 \mathrm{~h}$ at $37^{\circ} \mathrm{C}$, followed by incubation for $15 \mathrm{~min}$ at $70^{\circ} \mathrm{C}$ to stop the enzyme reaction. The $\mathrm{RT}$ product was diluted with $70 \mu \mathrm{l} \mathrm{H}_{2} \mathrm{O}$.

To amplify Bmi-1 cDNA, PCR reaction was performed with $2 \mu \mathrm{l}$ RT product using the following primers: $5^{\prime}$-AGCAGAAATGCATC GAACAA-3' (forward) and 5'-CCTAACCAG ATGAAGTTGCTGA-3' (reverse). The PCR amplification was allowed for 30 cycles at $94^{\circ} \mathrm{C} \quad(1 \mathrm{~min}) / 53^{\circ} \mathrm{C} \quad(1 \mathrm{~min}) / 72^{\circ} \mathrm{C} \quad(1 \mathrm{~min})$, followed by $7 \mathrm{~min}$ incubation at $72^{\circ} \mathrm{C}$. This PCR condition with $1 \mu \mathrm{l}$ RT product allowed for exponential amplification of the starting cDNA. To control for the contamination with genomic DNA, we also performed PCR reactions using the samples without prior RT reaction. No visible amplification was obtained without RT. Polymerase chain reaction amplifications of GPR1, Cyc $2 A, M M P$ 1, $M M P-3$, and glyceraldehyde-3-phosphate dehydrogenase $(G A P D H)$ were performed as described previously (Kang et al, 2003).

\section{Western blotting}

Whole-cell extracts (WCE) were fractionated by SDS-polyacrylamide gel electrophoresis (PAGE) and transferred to Immobilon protein membrane (Millipore, Billerica, MA, USA). The antibodies for $\mathrm{p} 16^{\mathrm{INK} 4 \mathrm{~A}}(\mathrm{Ab}-1)$ were purchased from Calbiochem (San Diego, CA, USA), and those for Bmi-1 (H99), $\beta$-actin (H-196), and CDK4 (C22) were from Santa Cruz Biotechnology (Santa Cruz, CA, USA).

\section{Bmi-1 gene amplification study}

Genomic DNA was isolated from five strains of NHOK, two normal human oral fibroblasts (NHOF), and eight cancer cell lines, including six OSCC cells. The DNAs were digested with EcoRI and HindIII to completion, electrophoresed in $0.8 \%$ agarose gel, and transferred to nylon membrane. Bmi-1 genomic sequences were probed by Southern hybridisation using radiolabelled probe synthesised from Bmi-1 cDNA or GAPDH cDNA, according to the methods described elsewhere (Kang et al, 1998). The Bmi-1 radioactive signal was detected by PhosphorImager and quantitated against that of GAPDH. The normalised quantitated values were used for statistical test (one way ANOVA) to compare the mean Bmi-1 radioactive signals in the NHOK cultures and in the OSCC cell lines.

\section{Immunohistochemical staining of Bmi-1 in paraffin- embedded tissues}

In situ Bmi-1 expression was determined in oral mucosal tissue samples with normal $(n=8)$, dysplastic $(n=9)$, or cancerous $(n=10)$ histopathology obtained from the Oral pathology diagnostic laboratoryat the University of California at Los Angeles School of Dentistry. The specimens were collected and processed according to the guidelines of the University of California at Los Angeles institutional review board. Immunohistochemistry was carried out with anti-Bmi-1 antibody (H-99, Santa Cruz, CA, USA) on 4 - $\mu$ m-thick sections according to the methods described elsewhere (Kim et al, 2004a). The samples were counterstained with haematoxylin. Bmi-1 staining intensity per each sample was arbitrarily scored by an oral pathologist as negative ( -$)$, barely detectable $(+/-)$, weak $(+)$, moderate $(++)$, or strong $(+++$; see 2$)$. In situ Bmi-1 staining was also performed in cultured NHOK and SCC4 cells according to the previously described method (Kang et al, 2000).

\section{In situ staining for cellular senescence}

Normal human oral keratinocytes cultures infected with the lentiviral vectors (LV-GFP and LV-Bmi-1i) were fixed in $2 \%$ formaldehyde $/ 0.2 \%$. glutaraldehyde for 3-5 min at room temperature. The cells were then stained for senescence-associated $\beta$-galactosidase (SA $\beta$-Gal) activity in freshly prepared staining solution (Dimri et al, 1995). The presence of SA $\beta$-Gal activity was evidenced by a dark-green colour in the perinuclear cytoplasmic region.

\section{Lentiviral vector construction and use of short-hairpin RNA (shRNA)}

We utilised the lentivirus-based shRNA expression plasmid pLL3.7 to knockdown the expression of endogenous Bmi-1. The detailed method of using pLL3.7 to construct the lentivirus expressing shRNA is described elsewhere (Rubinson et al, 2003). We constructed pLL3.7-Bmi-1i using double-stranded oligonucleotide cassette containing the Bmi-1 target sequence (5'-AAGGAATGGTCCACTTCCATT- $3^{\prime}$ ) as described previously (Bracken et al, 2003). The lentiviral vectors, LV-GFP and LV-Bmi-1i were prepared by transfecting $293 \mathrm{~T}$ cells with the RNA interference (RNAi) plasmids, respectively, pLL3.7 (insertless plasmid) and pLL3.7-Bmi-1i, using calcium phosphate transfection method in the presence of the packaging plasmid pCMV $\Delta \mathrm{R} 8.2 \mathrm{Vprx}$, and the envelope plasmid pCMV-VSV-G (Naldini et al, 1996). We constructed a lentivirus vector targeting the expression of $h T E R T$ (LV-hTERTi) using the plasmid pLL3.7-hTERTi, which expresses the shRNA containing the hTERT target sequence $\left(5^{\prime}-\right.$ GGCCGATTGTGAACATGGA-3'; nucleotides 1947-1965 of the hTERT mRNA sequence, see GenBank Accession NM 198255). As a 
negative control, we constructed another lentiviral vector (LVCont.), which expresses nonfunctional shRNA containing the hTERT mRNA sequences (5'- GAACGTGCTGGCCTTCGGC-3'; nucleotides 337-357) that fails to inhibit the endogenous expression of hTERT. The viral supernatant was collected at 24$36 \mathrm{~h}$ after transfection and concentrated by ultracentrifugation, as previously described (Stewart et al, 1999). Ultracentrifugation led to the concentration of the original viral supernatant by at least 12.5 fold. Rapidly proliferating NHOK, SCC4, and BaP-T cells were infected with $1 \mathrm{ml}$ of the concentrated virus (LV-GFP, LV-Cont. LV-Bmi-1i, and/or LV-hTERTi) in the presence of $6 \mu \mathrm{g} \mathrm{ml}^{-1}$ polybrene for $3 \mathrm{~h}$. This infection scheme invariably resulted in $>90 \%$ infection efficiency determined by the percentage cells labelled with green fluorescence. The infected cells were photographed using an inverted epifluorescence microscope (Nikon, Melvill, NJ, USA).

\section{RESULTS}

\section{Bmi-1 is overexpressed in OSCC cells and tissues}

To determine the association between Bmi-1 overexpression and oral carcinogenesis, we compared the expression levels of Bmi-1 in two independent cultures of NHOK and seven OSCC cells by semiquantitative RT-PCR (Figure 1A and Table 1). RKO and HeLa cells, representing the colorectal and cervical cancer cells, respectively, were also included for comparison. All tested cancer cell lines expressed significantly higher level of Bmi-1 compared with those of NHOK. Replicating NHOK (strain 01-4, population doubling (PD) 16) expressed higher level of Bmi-1 than the senescing cells (strain 01-4, PD 18 and 05-1, PD 20). The Bmi-1 expression level was also determined by Western blotting in NHOK and the OSCC cell lines (Figure 1B). Bmi-1 protein was weakly detected in NHOK cultured in serum-free KGM and was not altered by the culture conditions (data not shown). As Bmi-1 is known to negatively regulate the expression of $\mathrm{p} 16^{\mathrm{INK} 4 \mathrm{~A}}$ in some cells (Jacobs et al, 1999), we checked for the correlation between the expression levels of Bmi-1 and $\mathrm{p} 16^{\mathrm{INK} 4 \mathrm{~A}}$ in our experimental system. Bmi-1 protein expression level was notably higher in most of the OSCC cell lines compared with that of NHOK, but did not correlate with the expression level of $\mathrm{p} 16^{\mathrm{INK} 4 \mathrm{~A}}$, which correlated more closely with the human papillomavirus (HPV) infection status (Table 1).

Bmi-1 protein expression in situ was determined by immunohistochemical staining of paraffin-embedded oral mucosal tissues with varying degrees of histopathology that covers the entire spectrum of oral carcinogenesis (Figure 1C). Bmi-1 protein
A

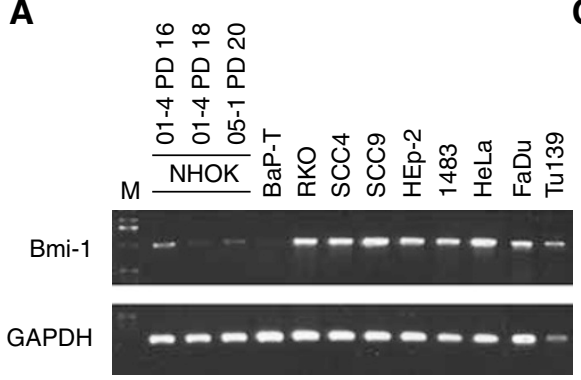

B

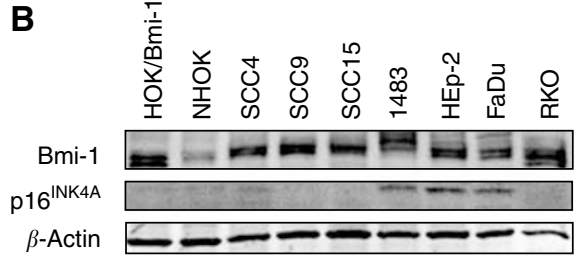

C

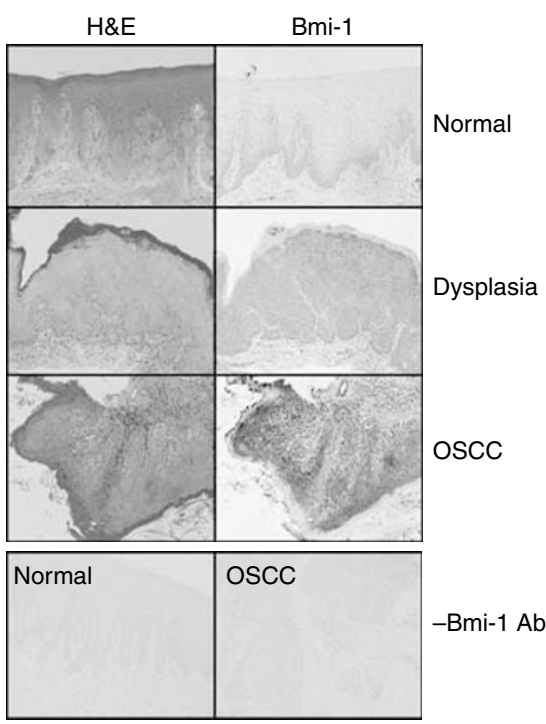

D

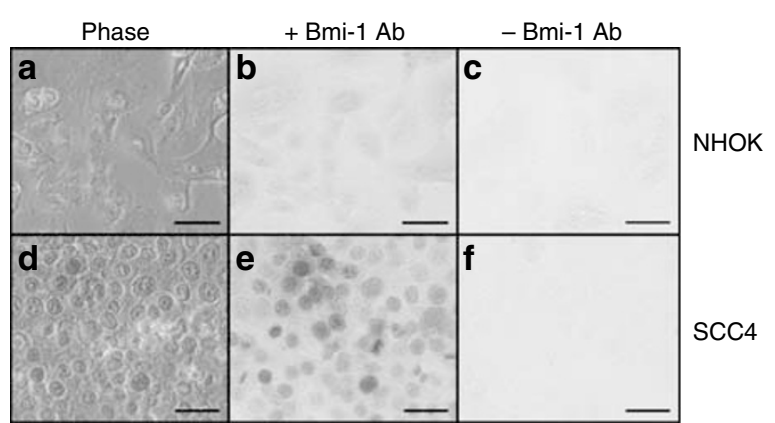

Figure I Bmi-I is overexpressed in the cancer cells derived from OSCC. (A) Endogenous Bmi-I expression level was compared by semi-quantitative RT-PCR in NHOK (OI-4 and 05-I) and nine cancer cell lines including seven OSCC cell lines. Glyceraldehyde-3-phosphate dehydrogenase was amplified as a loading control. (B) Western blotting was performed to compare the Bmi-I protein expression levels in NHOK and OSCC cells. HOK/Bmi-I, overexpressing exogenous Bmi-I (Kim et al, 2006), was included as a positive control for Bmi-I expression. In the same samples, we probed for the level of

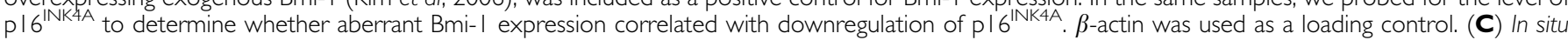
immunohistochemistry was performed with oral mucosal tissue specimens showing the histological features of normal $(n=8)$, dysplasia $(n=9)$, and OSCC $(n=10)$. The representative examples of histology (left panel, haematoxylin-eosin staining) and the Bmi-I staining (right panel) are shown in this figure. Bmi-I expression was detected by DAB staining (brown color). As negative controls, we included normal and OSCC specimens subjected to the staining procedure in the absence of specific Bmi-I antibody (-Bmi-I Ab). The images were captured with original magnification of $\times 100$. $(\mathbf{D}) \mathrm{NHOK}(\mathrm{a}-\mathrm{c})$ and SCC4 $(d-f)$ cells were fixed, permeabilised, and stained for Bmi-I by indirect immunoperoxidase method. Bar $=100 \mu \mathrm{m}$. 
expression, revealed by brown 3,3'-diaminobenzidine hydrochloride $(\mathrm{DAB})$ staining, was weakly detectable and limited to the basal cell layer of normal stratified epithelium $(n=8)$ and was not found in the upper spinosum and corneum layers. In contrast, all preneoplastic oral epithelial tissues $(n=9)$ displaying mild, moderate, and severe dysplasia as well as malignant oral lesions $(n=10)$ showed elevated Bmi-1 staining compared with those of the normal tissues (Table 2). The Bmi-1 staining in these aberrant tissues was detected in most of the epithelial layers containing viable cells, including stratum basale, spinosum, and granulosum.

Table I The OSCC cell lines and the status of Bmi- I, p I $6^{\text {INK4A }}$, p53, and HPV infection

\begin{tabular}{|c|c|c|c|c|c|}
\hline Cells & $\begin{array}{l}\text { Tissue } \\
\text { origin }\end{array}$ & Bmi- I & $p / 6^{\text {INK4Ab }}$ & p53 & $\begin{array}{l}\text { HPV } \\
\text { status }\end{array}$ \\
\hline $\mathrm{BaP}-\mathrm{T}^{\mathrm{c}}$ & gingiva & - & + & Targeted by E6 & +/type 16 \\
\hline $\operatorname{SCC} 4^{d}$ & tongue & + & + & mutant & - \\
\hline sCC9 $^{d}$ & tongue & + & - & - & - \\
\hline $\operatorname{sCC} 15^{d}$ & tongue & + & - & - & - \\
\hline HEp-2 ${ }^{d}$ & larynx & + & + & Targeted by E6 & +/type 18 \\
\hline $1483^{e}$ & oral & + & + & Targeted by E6 & +/type 18 \\
\hline $\mathrm{FaDu}^{\mathrm{d}}$ & pharynx & + & + & Mutant & - \\
\hline Tul39f & larynx & + & - & Mutant & - \\
\hline $\mathrm{RKO}^{\mathrm{g}}$ & colorectum & + & - & wild-type & - \\
\hline $\mathrm{HeLa}^{\mathrm{d}}$ & cervix & + & + & Targeted by E6 & +/type 18 \\
\hline
\end{tabular}

${ }^{a}$ Bmi- I overexpression was determined based on the RT-PCR and Western blotting results (Figure I). Positive indicates enhanced expression compared with the baseline (negative) expression level found in the NHOK cultures. ${ }^{\mathrm{p}} \mathrm{p} / 6^{\mathrm{INK} 4 \mathrm{~A}}$ expression status

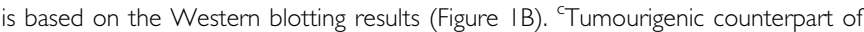
NHOK (Park et al, 1995). 'Purchased from American Type Culture Collection. The protein expression patterns for these cell lines were based on Munro et al, 1999. ${ }^{e}$ Gift of P. Sacks (Univ. Texas, Houston, TX, USA). 'Gift of G. Clayman (Univ. Texas, Houston, TX, USA). ' Gift of M. Kastan (Johns Hopkins, Baltimore, MD, USA).
Stratum corneum and lucidum did not show Bmi-1 staining owing to the lack of viable cells in these layers. We also compared the levels of Bmi-1 staining in situ in cultured normal and cancer cells. Normal human oral keratinocytes and SCC4 were subjected to indirect immunopreoxidase staining for Bmi-1 using anti-Bmi-1 antibody. Diffuse cytoplasmic Bmi-1 staining was noted in NHOK, whereas SCC4 cells showed strong intranuclear and faint cytoplasmic Bmi-1 staining (Figure 1D). These data are in keeping with the Western blotting result, which showed notable increase in the Bmi-1 expression level in SCC4 cells compared with that of NHOK. The above results indicate that the elevated Bmi-1 expression is associated with preneoplastic oral lesions and is sustained in oral cancer.

\section{Bmi-1 gene is not amplified in the OSCC cell lines}

To determine whether the Bmi-1 overexpression in the OSCC cells resulted from gene amplification, we compared the amount of Bmi-1 genomic sequences by Southern blotting in normal and cancer cells. We included five strains of NHOK, two NHOF strains, and seven cancer cell lines including six OSCC cell lines. The $B m i$-1-specific signals were obtained at $4.3 \mathrm{~kb}, 3.1 \mathrm{~kb}$, and $2.4 \mathrm{~kb}$ fragments, and were compared among the tested samples as its ratio to that of GAPDH (Figure 2). We found that there was no statistically significant difference in the relative abundance of the $B m i-1$ genomic sequences between the normal and the cancer cells. The Bmi- 1 overexpression in OSCC may result from the mechanisms not involving gene amplification, such as promoter activation.

\section{Bmi-1 knockdown inhibits cellular proliferation of normal and cancer cells}

To investigate the biological role of Bmi-1, we knocked down the expression of endogenous Bmi-1 by RNAi in SCC4 cells and

Table 2 Bmi-I immunoreactivity in situ is elevated in the oral epithelium with dysplastic and cancerous histopathology

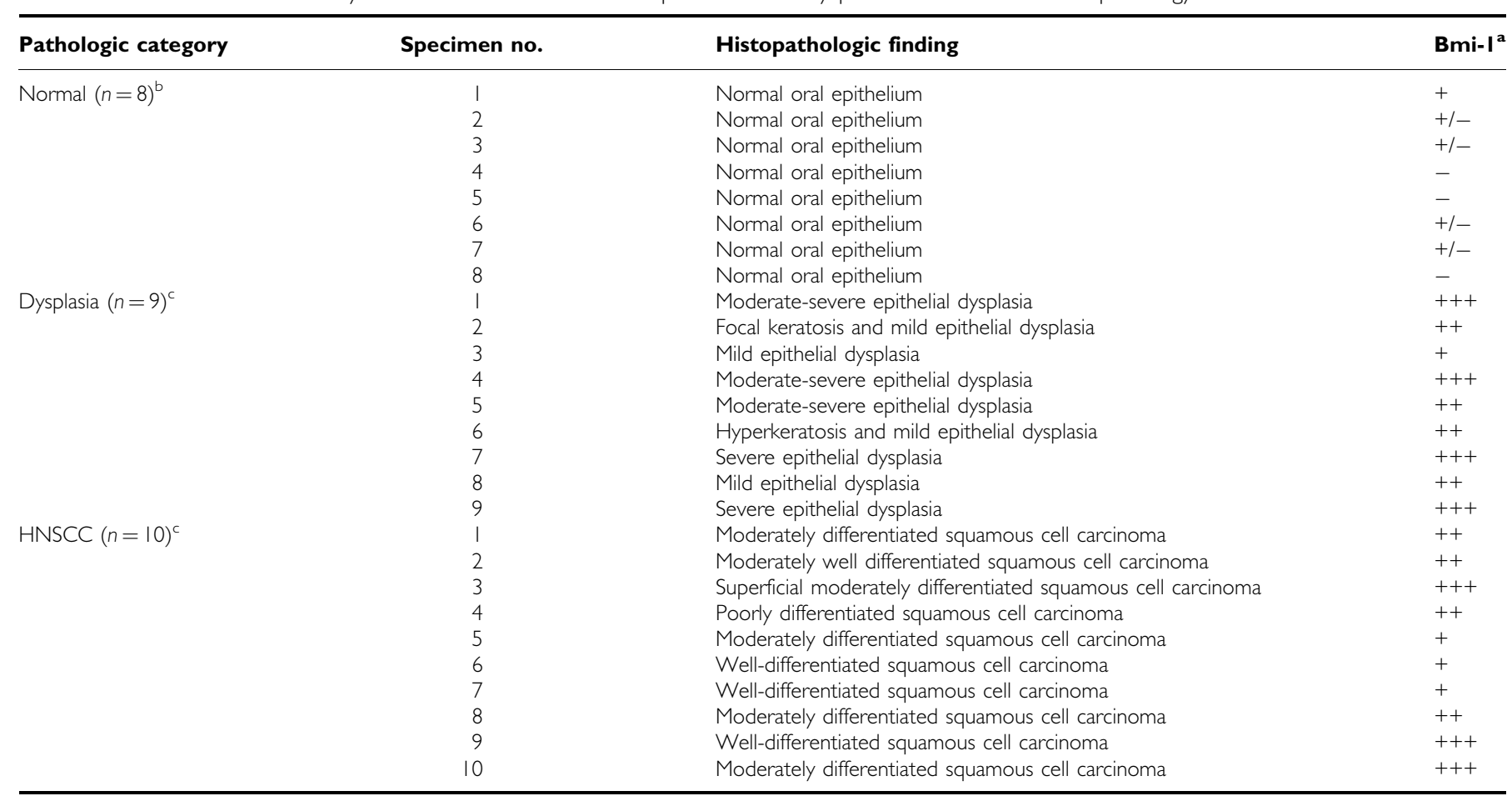

${ }^{a}$ The level of Bmi- I immunostaining per each specimen was scored as negative $(-)$, barely detectable $(+/-)$, weak $(+)$, moderate $(++)$, or strong $(+++)$ by an oral pathologist, noting the level of chromogenic development after addition of the DAB substrate. The scoring was confirmed blindly by an individual without prior knowledge or understanding of the nature of the tissue specimens. ${ }^{\mathrm{b}} \mathrm{Bmi}-\mathrm{I}$ in normal oral epithelium was limited to the basal cell layer (Figure IC). ${ }^{\mathrm{c}} \mathrm{Bmi}-\mathrm{I}$ staining in the dysplastic and the OSCC samples was homogenously detected in most of the epithelial layers including stratum basale, spinosum, and granulosum (Figure IC). 


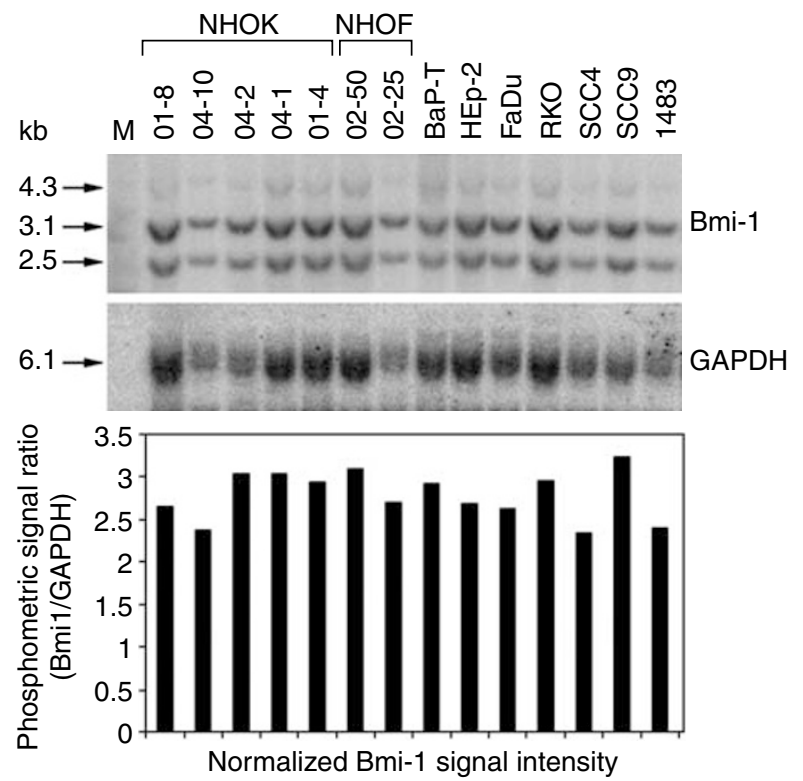

Figure 2 Bmi-I gene is not amplified in OSCC. Genomic DNAs from five different NHOK strains, two NHOF strains, and seven cancer cell lines were digested with EcoR I and Hind III and transferred for probing. Radiolabelled probes synthesised from Bmi-I or GAPDH cDNA were hybridised sequentially onto the membrane. The phosphometric intensities were plotted as the ratio of Bmi-I to GAPDH. The lack of statistical difference $(P>0.05)$ in the levels of Bmi-I radioactive signals was determined by unpaired T-test (one-ways ANOVA) between the NHOK and the cancer groups.

exponentially replicating NHOK. For this purpose, we constructed a lentiviral vector (LV-Bmi-1i) capable of expressing shRNA targeting Bmi-1 using the pLL3.7 plasmid, which also contains the green fluorescent protein (GFP) expression cassette under a heterologous promoter (Rubinson et al, 2003). SCC4 cells and replicating NHOK (strain $05-10$, PD 10) were infected with LVBmi-1i and the control lentiviral vector (LV-GFP) expressing GFP alone. At 3 days post-infection, more than $95 \%$ of the cultures infected with LV-GFP or LV-Bmi-1i demonstrated green fluorescence (Figure $3 \mathrm{~A}$ ), indicating efficient infectivity. Also, at 3 days post-infection, the endogenous Bmi-1 expression level was decreased by 83 and $85 \%$, respectively, in NHOK and SCC4 cells infected with LV-Bmi-1i if compared with the cells infected with LV-GFP (Figure 3B). The SCC4 cells were maintained in culture for longer than 10 days post-infection, during which time the cells infected with LV-Bmi-1i showed a marked reduction in proliferative capacity (Figure 3A). The LV-GFP-infected SCC4 cells continued to replicate beyond the 10-day period, whereas the SCC4 culture exposed to LV-Bmi-1i contained sparse, flattened cells with GFP expression.

At 3 days post-infection, the majority of NHOK also demonstrated the fluorescence signal (Figure 4A). Normal human oral keratinocytes infected with LV-GFP underwent 16 PDs before the onset of senescence, whereas those infected with LV-Bmi-1i expressed increased SA $\beta$-Gal activity and showed notable retardation of proliferation following the infection, completing only 12 cumulative PDs (Figure 4B). To determine whether the retarded proliferation in NHOK infected with LV-Bmi-1i represented the cellular senescence response, we compared the expression levels of $G P R 1, M M P-1$, and $M M P-3$, which are the molecular markers of keratinocyte senescence (Kang et al, 2003). Semi-quantitative RT-PCR was performed with NHOK after 10 days post-infection (Figure 4C). Expression levels of GPR1, MMP-1, and MMP-3 were induced in NHOK infected with LV-Bmi-1i compared with those infected with LV-GFP. Also, the cells with
A
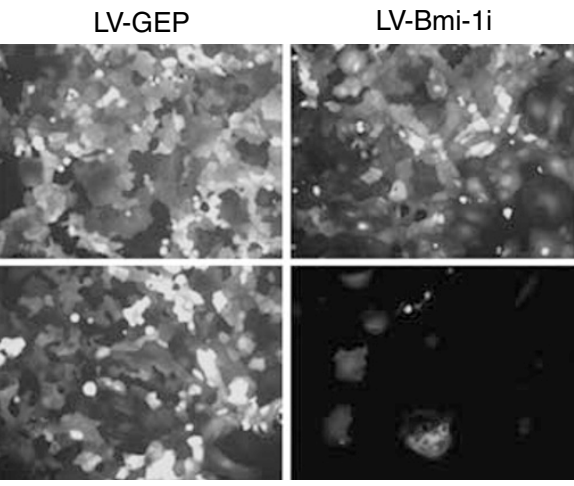

B
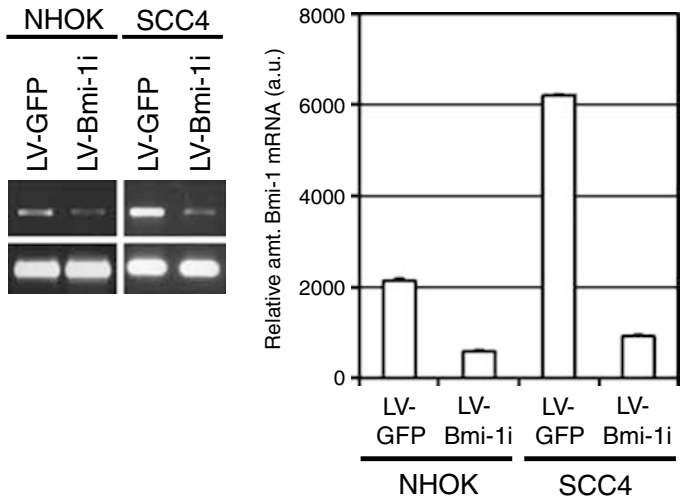

Figure 3 Inhibition of endogenous Bmi-I causes replication arrest in SCC 4 cells. (A) Rapidly proliferating SCC4 cells were infected with LV-GFP or LV-Bmi-li. After 3 or 10 days, the images were obtained for GFP revealing those cells that were originally infected by the viral vectors. Original magnification, $\times$ 100. (B) Three days after infection of $\mathrm{NHOK}(05$ I0) and SCC4 cells with LV-GFP or LV-Bmi- Ii, the level of Bmi-I transcript was measured by semi-quantitative RT-PCR. The extent of Bmi-I knockdown by LV-Bmi- I i was quantitated by Scion Image software against those of GAPDH amplification.

Bmi-1 knockdown showed diminution of $C y c 2 A$ mRNA, of which the expression level is associated with exponential replication of NHOK (Kang et al, 2003). However, the cells infected with LV-Bmi-1i did not exhibit elevation of p16 ${ }^{\mathrm{INK} 4 \mathrm{~A}}$ (Figure $4 \mathrm{D}$ ). These results demonstrated that the loss of endogenous Bmi-1 expression led to diminution of the cell proliferation capacity in both SCC4 cells and NHOK, in the absence of induced $\mathrm{p} 16^{\mathrm{INK} 4 \mathrm{~A}}$ expression level.

The involvement of the $\mathrm{p} 16^{\mathrm{INK} 4 \mathrm{~A}}$ in the cell proliferation arrest triggered by Bmi-1 knockdown was further analysed by utilising the BaP-T cells, which possess aberrant $\mathrm{p} 16^{\mathrm{INK} 4 \mathrm{~A}} / \mathrm{pRb}$ pathway owing to the expression of HPV oncoprotein E7 (Park et al, 1995). Actively proliferating BaP-T cells were infected with LV-GFP or LV-Bmi-1i vectors. For comparison, we also infected the cells with LV-hTERTi, targeting the cellular telomerase activity, which demonstrated effective anticancer activity ( $\mathrm{Li}$ et al, 2004). The cells were maintained in culture for 10 days post-infection, and the total numbers of the infected cells were determined. All of the lentiviral vectors demonstrated highly efficient infectivity even after 1 day post-infection (Figure 5). However, infection of BaP-T cells with LV-Bmi-1i or LV-hTERTi effectively inhibited cellular proliferation and led to loss of viability as early as 4 days postinfection (Figure 6). BaP-T cells were also infected with LV-Cont. expressing nonfunctional shRNA against hTERT sequence. These cells exhibited no phenotypic alteration compared with those infected with LV-GFP (Figure 5D). These results suggest that the intact $\mathrm{p} 16^{\mathrm{INK} 4 \mathrm{~A}} / \mathrm{pRb}$ checkpoint pathway is not necessary for the Bmi-1i-induced OSCC replication arrest and death. 
A

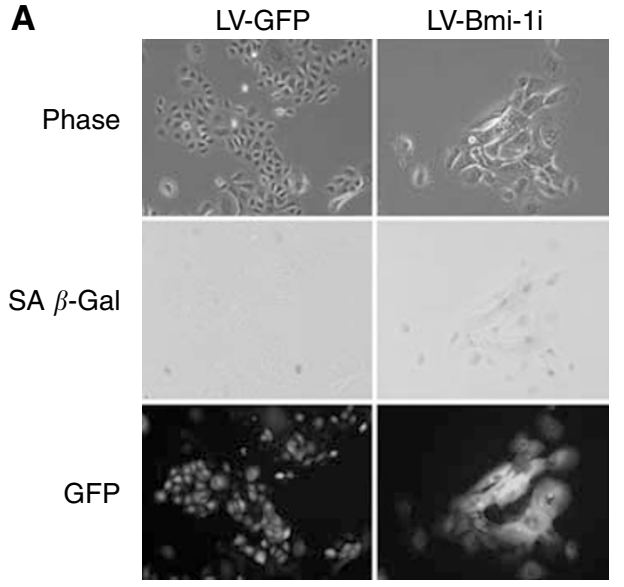

C

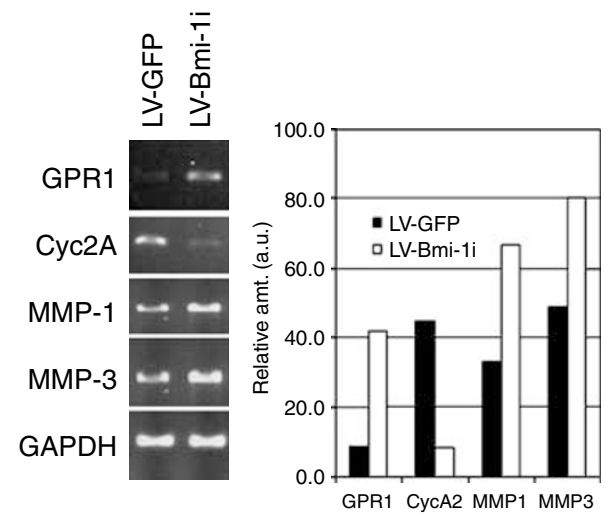

B

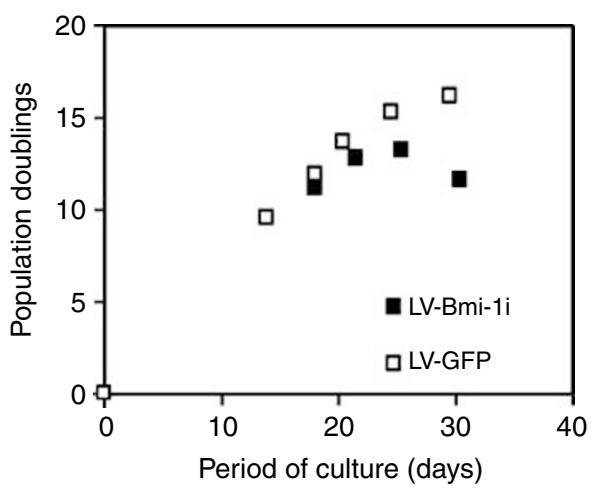

D

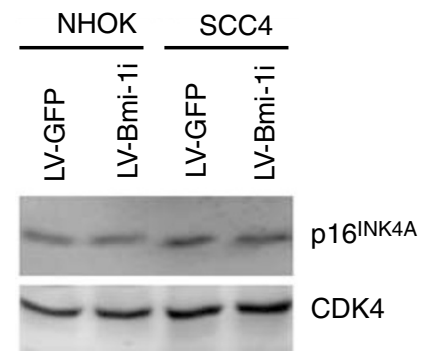

Figure 4 Inhibition of endogenous Bmi-I causes premature senescence in NHOK. (A) Rapidly proliferating NHOK (05-I0) was infected with LV-GFP or LV-Bmi-I i. Phase contrast photographs, SA $\beta$-Gal staining, and GFP fluorescence were obtained 10 days after virus infection. Original magnification, $\times 100$. (B) Proliferation kinetics of NHOK infected with LV-GFP or LV-Bmi- Ii was determined and plotted against time in culture. (C) NHOK cultures were harvested at 10 days after infection with LV-GFP or LV-Bmi- Ii, and the expression levels of GPRI, Cyc2A, MMP-I, and MMP-3 were determined by semiquantitative RT-PCR. The band intensities were quantitated and plotted by Scion Image software against those of GAPDH amplification. (D) NHOK (0510) and SCC 4 cells infected with LV-GFP or LV-Bmi- I i were harvested at 10 days after infection, and Western blotting was performed with $100 \mu \mathrm{g}$ WCE for p I $6^{\text {INK } 4 A}$. CDK4 was detected as a loading control.

\section{DISCUSSION}

In the present study, we examined the possible involvement of the PcG protein Bmi-1 in oral carcinogenesis by (1) comparison of the Bmi-1 protein and RNA expression levels in normal and OSCC cells and tissues and (2) knockdown of endogenous Bmi-1 in normal and OSCC cells. The first part of the study revealed that Bmi-1 overexpression was consistently observed in the OSCC cells and tissues compared with the normal controls. The level of Bmi-1 expression in the OSCC cells was comparable to that of the cancer cells, that is, RKO and HeLa, derived from other cancer types. Importantly, Bmi-1 overexpression was also observed in $100 \%$ (9/ 9) of the preneoplastic oral mucosal tissues which included those with mild, moderate, or severe epithelial dysplasia. This finding indicates that Bmi-1 overexpression occurs very early during oral carcinogenesis and may be used as a biomarker of preneoplastic oral lesions. A recent study examined the expression status of Bmi-1 in the lung SCC precursor lesions, which showed Bmi-1 expression in $48 \%$ of the cases by immunofluorescent staining (Breuer et al, 2005). Thus, Bmi-1 overexpression and the development of preneoplastic lesions are more closely associated in the oral mucosa than in the bronchial tissues.

The mechanism leading to the enhanced Bmi-1 expression in OSCC cells is not clear. However, we ruled out the possibility of gene amplification by Southern blotting, which showed comparable level of Bmi-1 genomic sequences in normal and OSCC cells.
Using the Bmi-1 promoter-luciferase construct, we found that the promoter activity was strongly induced in the OSCC cells compared with that of NHOK (unpublished observation), indicating that Bmi-1 overexpression results from promoter activation. Recent studies showed that Bmi-1 is a direct transcriptional target of c-Myc in human fibroblasts (Guney et al, 2006) and of E2F-1 in neuroblastomas (Nowak et al, 2006). c-Myc was found to be frequently amplified in OSCCs by comparative genomic hybridisation (Chen et al, 2004). Thus, $c$-Myc-dependent Bmi-1 promoter activation may account for the enhanced gene expression during dysplastic cell transformation in oral carcinogenesis, although the extent to which c-Myc regulates the Bmi-1 promoter activity in oral carcinogenesis needs further investigation.

Bmi-1 knockdown led to inhibition of cellular replication in both NHOK and OSCC cells. However, the cellular response seems to be different between the normal and cancer cells. In NHOK, Bmi-1 knockdown did not elicit an immediate response of replication arrest and/or loss of viable cells, although the cellular replication rate was notably reduced and the senescence prematurely triggered. In contrast, SCC4 and BaP-T cells underwent rapid arrest of replication upon infection with LV-Bmi-1i and showed drastic decrease in the viable cell number. After 8-10 days post-infection, the majority of the OSCC cells detached from the culture dish (Figures $3 \mathrm{~A}$ and 5). Comparison of the replication kinetics of the cells infected with the LV-GFP or LV-Bmi-1i also demonstrates clear difference in the cellular response between 
A

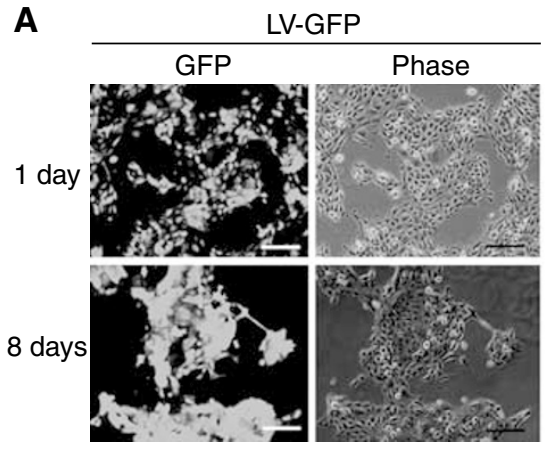

C

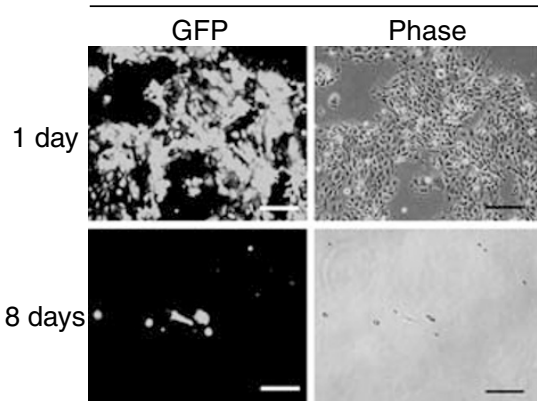

B

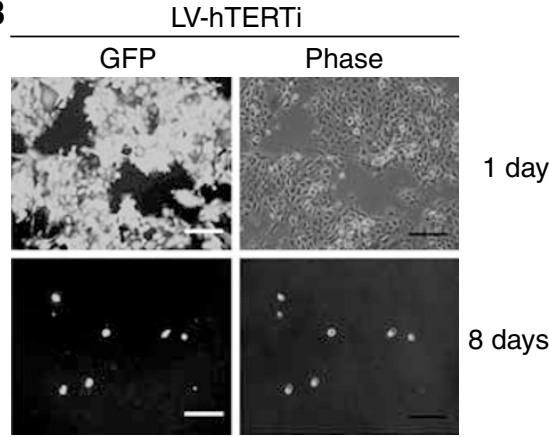

D
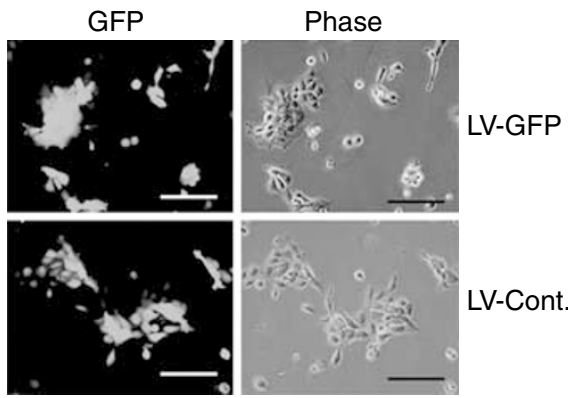

Figure 5 Inhibition of endogenous Bmi-I led to effective loss of viability in BaP-T cells. Rapidly proliferating BaP-T cells were infected with LV-GFP (A), LV-hTERTi (B), LV-Bmi-li $(\mathbf{C})$, or LV-Cont (D). (A-C) The infected cells were labelled with green fluorescence owing to the GFP expression from the pLL3.7 parental lentiviral vector and shown along with the phase contrast view after I day or 8 days post-infection. The cells infected with LV-GFP were passaged owing to reaching confluence after 3-4 days, whereas those infected with LV-Bmi-Ii or LV-hTERTi were maintained in the same dish without passaging for the period of observation. (D) In another experiment, BaP-T cells were infected with LV-GFP or LV-Cont. and maintained in parallel for 9 days and photographed. In this experiment, no notable differences in cellular morphology, replication capacity, or viability were noted between the two groups. Bar $=200 \mu \mathrm{m}$.

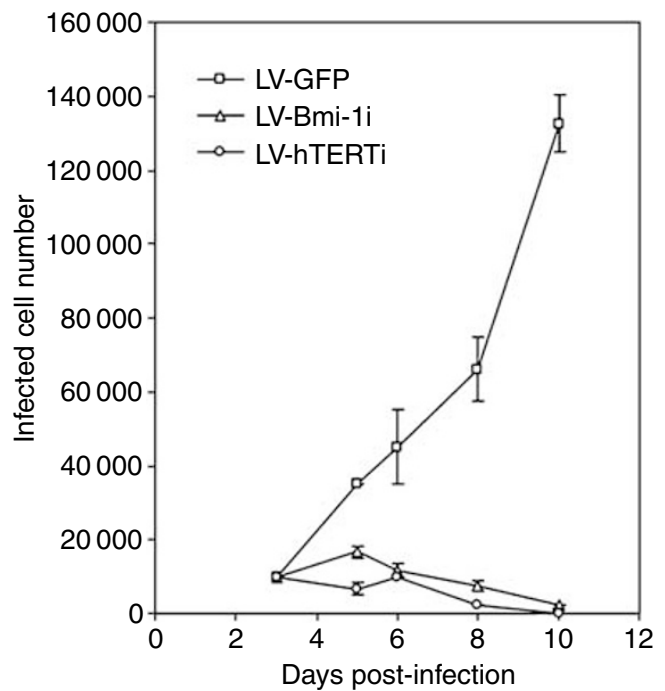

Figure 6 Effective loss of viability in BaP-T cells infected with LV-Bmi- Ii or LV-hTERTi. Viable BaP-T cells infected with LV-GFP, LV-Bmi-I, or LVhTERTi shown in Figure 5 were quantitated and plotted against period of culture. The total numbers of fluorescence-labelled adherent cells were determined at $3,5,6,8$, and 10 days post-infection.

NHOK and the BaP-T cells (Figures $4 \mathrm{~B}$ and 6). Our result is consistent with a recent report demonstrating cancer-specific cytotoxic effect of Bmi-1 knockdown in neuroblastoma cells (Liu et al, 2006). The differential effect of Bmi-1 knockdown in the normal and cancer cells may be beneficial if Bmi-1 were to be targeted for anticancer therapy.
The LV-Bmi-1i vector was effective against the BaP-T cells, which express HPV type 16 E7 (Park et al, 1995). Thus, Bmi-1imediated growth inhibition may not require intact $\mathrm{p} 16^{\mathrm{INK} 4 \mathrm{~A}} / \mathrm{pRb}$ checkpoint pathway, as it is also reflected in the absence of p16 ${ }^{\mathrm{INR} 4 \mathrm{~A}}$ induction in the NHOK and SCC4 cells after Bmi-1 knockdown. The inverse correlation between Bmi-1 and p16 ${ }^{\mathrm{INK} 4 \mathrm{~A}}$ protein expression levels was not evident in the OSCC cell lines in our study (Figure 1B). Furthermore, we recently reported that expression of exogenous Bmi-1 in NHOK led to significant extension ( 2.7 fold) of replicative life span but did not efficiently downregulate the expression of $\mathrm{p} 16^{\mathrm{INK} 4 \mathrm{~A}}$ (Kim et al, 2006). It is possible that Bmi-1 targets other important regulators of cell division in $\mathrm{NHOK}$, such as $\mathrm{p} 14^{\mathrm{ARF}}$ or $\mathrm{p} 15^{\mathrm{INK} 4 \mathrm{~B}}$, as previously suggested (Jacobs et al, 1999). Several recent studies also showed that the aberrant Bmi-1 expression is not necessarily associated with downregulation of $\mathrm{p} 16^{\mathrm{INK} 4 \mathrm{~A}}$ expression (Dukers et al, 2004; Breuer et al, 2005). Also, Bracken et al (2006) recently identified numerous cellular genes targeted by Bmi-1 other than p16 ${ }^{\mathrm{INK} 4 \mathrm{~A}}$ using microarray-based expression screening and chromatin immunoprecipitation (ChIP)-on-chip analysis. These findings support the possibility that Bmi-1 elicits its oncogenic property during oral carcinogenesis in $\mathrm{p}^{16^{\mathrm{INK} 4 \mathrm{~A}}}$-independent manner.

\section{ACKNOWLEDGEMENTS}

We thank Dr Sacks for 1483, Dr Clayman for Tu-139, and Dr Kastan for RKO cells. This work was supported in part by the grants DE15316 (MKK) and DE14147 (N-HP) funded by the NIDCR/NIH and by the Oral and Maxillofacial Surgery Foundation Grant (MKK). 


\section{REFERENCES}

Bea S, Tort F, Pinyol M, Puig X, Hernandez L, Hernandez S, Fernandez PL, van Lohuizen M, Colomer D, Campo E (2001) BMI-1 gene amplification and overexpression in hematological malignancies occur mainly in mantle cell lymphomas. Cancer Res 61: 2409-2412

Bracken AP, Dietrich N, Pasini D, Hansen KH, Helin K (2006) Genomewide mapping of Polycomb target genes unravels their roles in cell fate transitions. Genes Dev 20: $1123-1136$

Bracken AP, Pasini D, Capra M, Prosperini E, Colli E, Helin K (2003) EZH2 is downstream of the $\mathrm{pRB}-\mathrm{E} 2 \mathrm{~F}$ pathway, essential for proliferation and amplified in cancer. EMBO J 22: $5323-5335$

Breuer RH, Snijders PJ, Sutedja GT, Sewalt RG, Otte AP, Postmus PE, Meijer CJ, Raaphorst FM, Smit EF (2005) Expression of the p16(INK4a) gene product, methylation of the p16(INK4a) promoter region and expression of the polycomb-group gene BMI-1 in squamous cell lung carcinoma and premalignant endobronchial lesions. Lung Cancer 48: $299-306$

Campisi J (2005) Senescent cells, tumor suppression, and organismal aging: good citizens, bad neighbors. Cell 120: $513-522$

Chen JH, Ozanne SE, Hales CN (2005) Heterogeneity in premature senescence by oxidative stress correlates with differential DNA damage during the cell cycle. DNA Repair 4: 1140-1148

Chen YJ, Lin SC, Kao T, Chang CS, Hong PS, Shieh TM, Chang KW (2004) Genome-wide profiling of oral squamous cell carcinoma. J Pathol 204: $326-332$

Dimri GP (2005) What has senescence got to do with cancer? Cancer Cell 7: $505-512$

Dimri GP, Lee X, Basile G, Acosta M, Scott G, Roskelley C, Medrano EE, Linskens M, Rubelj I, Pereira-Smith O, Peacocke M, Campisi J (1995) A biomarker that identifies senescent human cells in culture and in aging skin in vivo. Proc Natl Acad Sci USA 92: 9363-9367

Dimri GP, Martinez JL, Jacobs JJ, Keblusek P, Itahana K, van Lohuizen M, Campisi J, Wazer DE, Band V (2002) The Bmi-1 oncogene induces telomerase activity and immortalizes human mammary epithelial cells. Cancer Res 62: 4736-4745

Dukers DF, van Galen JC, Giroth C, Jansen P, Sewalt RG, Otte AP, KluinNelemans HC, Meijer CJ, Raaphorst FM (2004) Unique polycomb gene expression pattern in Hodgkin's lymphoma and Hodgkin's lymphomaderived cell lines. Am J Pathol 164: 873-881

Gil J, Bernard D, Martinez D, Beach D (2004) Polycomb CBX7 has a unifying role in cellular lifespan. Nat Cell Biol 6: 67-72

Guney I, Wu S, Sedivy JM (2006) Reduced c-Myc signaling triggers telomere-independent senescence by regulating Bmi-1 and p16(INK4a). Proc Natl Acad Sci USA 103: 3645 - 3650

Harley CB, Futcher B, Greider CW (1990) Telomeres shorten during ageing of human fibroblasts. Nature 345: 458-460

Itahana K, Campisi J, Dimri GP (2004) Mechanisms of cellular senescence in human and mouse cells. Biogerontol 5: 1-10

Itahana K, Zou Y, Itahana Y, Martinez JL, Beausejour C, Jacobs JJ, van Lohuizen M, Band V, Campisi J, Dimri GP (2003) Control of the replicative life span of human fibroblasts by p16 and the polycomb protein Bmi-1. Mol Cell Biol 23: 389-401

Jacobs JJ, Kieboom K, Marino S, DePinho RA, van Lohuizen M (1999) The oncogene and Polycomb-group gene bmi-1 regulates cell proliferation and senescence through the ink4a locus. Nature 397: 164-168

Kang MK, Bibb C, Baluda MA, Rey O, Park N-H (2000) In vitro replication and differentiation of normal human oral keratinocytes. Exp Cell Res 258: 288- 297

Kang MK, Guo W, Park N-H (1998) Replicative senescence of normal human oral keratinocytes is associated with the loss of telomerase activity without shortening of telomeres. Cell Growth \& Differ 9: 85-95

Kang MK, Kameta A, Shin K-H, Baluda MA, Kim HR, Park N-H (2003) Senescence-associated genes in normal human oral keratinocytes. Exp Cell Res 287: 272-281

Karlseder J, Smogorzewska A, de Lange T (2002) Senescence induced by altered telomere state, not telomere loss. Science 295: 2446-2449

Kim JH, Yoon SY, Jeong SH, Kim SY, Moon SK, Joo JH, Lee Y, Choe IS, Kim JW (2004a) Overexpression of Bmi-1 oncoprotein correlates with axillary lymph node metastases in invasive ductal breast cancer. Breast 13: $383-388$

Kim JH, Yoon SY, Kim CN, Joo JH, Moon SK, Choe IS, Choe YK, Kim JW (2004b) The Bmi-1 oncoprotein is overexpressed in human colorectal cancer and correlates with the reduced p16INK4a/p14ARF proteins. Cancer Lett 203: $217-224$

Kim RH, Kang MK, Shin K-H, Oo ZM, Han T, Baluda MA, Park N-H (2006) Bmi-1 cooperates with human papillomavirus type 16 E6 to immortalize normal human oral keratinocytes. Exp Cell Res doi:10.1016/ j.yexcr.2006.10.025

Lessard J, Sauvageau G (2003) Bmi-1 determines the proliferative capacity of normal and leukaemic stem cells. Nature 423: 255-260

Li S, Rosenberg JE, Donjacour AA, Botchkina IL, Hom YK, Cunha GR, Blackburn EH (2004) Rapid inhibition of cancer cell growth induced by lentiviral delivery and expression of mutant-template telomerase RNA and anti-telomerase short-interfering RNA. Cancer Res 64: $4833-4840$

Li Z, Cao R, Wang M, Myers MP, Zhang Y, Xu RM (2006) Structure of a Bmi-1-Ring1B polycomb group ubiquitin ligase complex. J Biol Chem 281: $20643-20649$

Liu L, Andrews LG, Tollefsbol TO (2006) Loss of the human polycomb group protein BMI1 promotes cancer-specific cell death. Oncogene 25: $4370-4375$

Munro J, Stott FJ, Vousden KH, Peters G, Parkinson EK (1999) Role of the alternative INK4A proteins in human keratinocyte senescence: evidence for the specific inactivation of p16INK4A upon immortalization. Cancer Res 59: $2516-2521$

Naldini L, Blomer U, Gallay P, Ory D, Mulligan R, Gage FH, Verma IM, Trono D (1996) In vivo gene delivery and stable transduction of nondividing cells by a lentiviral vector. Science 272: $263-267$

Nowak K, Kerl K, Fehr D, Kramps C, Gessner C, Killmer K, Samans B, Berwanger B, Christiansen H, Lutz W (2006) BMI1 is a target gene of E2F-1 and is strongly expressed in primary neuroblastomas. Nucl Acids Res 34: $1745-1754$

Ohtani N, Zebedee Z, Huot TJ, Stinson JA, Sugimoto M, Ohashi Y, Sharrocks AD, Peters G, Hara E (2001) Opposing effects of Ets and Id proteins on p16INK4a expression during cellular senescence. Nature 409: $1067-1070$

Park N-H, Gujuluva CN, Baek J-H, Min B-M, Cherrick HM, Shin K-H (1995) Combined oral carcinogenicity of HPV-16 and benzo(a)pyrene: an in vitro multistep carcinogenesis model. Oncogene 10: 2145-2153

Pirrotta V (1998) Polycombing the genome: PcG, trxG, and chromatin silencing. Cell 93: $333-336$

Ramirez RD, Morales CP, Herbert BS, Rohde JM, Passons C, Shay JW, Wright WE (2001) Putative telomere-independent mechanisms of replicative aging reflect inadequate growth conditions. Genes Dev 15: $398-403$

Rey O, Lee S, Park N-H (2000) Human papillomavirus type 16 E7 oncoprotein represses transcription of human fibronectin. J Virol 74: $4912-4918$

Rubinson DA, Dillon CP, Kwiatkowski AV, Sievers C, Yang L, Kopinja J, Zhang M, McManus MT, Gertler FB, Scott ML, Van Parijs L (2003) A lentivirus-based system to functionally silence genes in primary mammalian cells, stem cells and transgenic mice by RNA interference. Nat Genet 33: $401-406$

Serrano M, Lin AW, McCurrach ME, Beach D, Lowe SW (1997) Oncogenic ras provokes premature cell senescence associated with accumulation of p53 and p16INK4a. Cell 88: 593-602

Sparmann A, van Lohuizen M (2006) Polycomb silencers control cell fate, development and cancer. Nat Rev Cancer 6: 846-856

Stewart SA, Poon B, Jowett JBM, Xie Y, Chen ISY (1999) Lentiviral delivery of HIV-1 Vpr protein induces apoptosis in transformed cells. Proc Natl Acad Sci USA 96: 12039 - 12043

van Lohuizen M, Verbeek S, Scheijen B, Wientjens E, van der Gulden $H$, Berns A (1991) Identification of cooperating oncogenes in E mu-myc transgenic mice by provirus tagging. Cell 65: 737-752 